Mladen Turuk ${ }^{*}$

Bojan Morić Milovanović ${ }^{* *}$

Tihana Galic ${ }^{* * *}$

\title{
EMPIRIJSKA ANALIZA USPOREDBE EKSTRINZIČNIH I INTRINZIČNIH MOTIVACIJSKIH ČIMBENIKA IZMEĐU PODUZETNIKA I INTRAPODUZETNIKA
}

\begin{abstract}
Sažetak
Motivacija predstavlja čimbenik koji izaziva određeno željeno ponašanje, pri čemu različiti čimbenici određuju željeno ponašanje kod različitih tipova promatranih ekonomskih subjekata. Cilj rada je steći dublje razumijevanje glavnih razlika motivacije poduzetnika i intrapoduzetnika. U radu je pružen teorijski prikaz poduzetnika i intrapoduzetnikate su navedene najznačajnije sadržajne teorije motivacije. Također, u radu su prikazani različiti čimbenici motivacije koji su korišteni u istraživanju. Od ekstrizičnih motivacijskih čimbenika ispitivali su se novčana nagrada, izazov i trening, dok su se intrizični čimbenici ispitivali kroz moć, pripadnost i priznanje. Kako bi se ustanovilo navedeno provedeno je kvalitativno istraživanje te je u namjernom uzorku metodom polustandardiziranog intervjua ispitan utjecaj intrizičnih i ekstrizičnih čimbenika na motivaciju poduzetnika i intrapoduzetnika. Ustanovljeno je kako su poduzetnici više motivirani novcem i moći u usporedbi s onim što motivira intrapoduzetnike, a to su izazov i priznanje. Što se tiče treninga, pripadnosti i uspjeha, ti su faktori bili jednako motivirajući za poduzetnike i za intrapoduzetnike.

Ključne riječi: korporativno poduzetništvo, poduzetnik, intrapoduzetnik, kvalitativno istraživanje, motivacija
\end{abstract}

\section{Uvod}

Uvijek aktualna problematika poduzetništva dodatno dobiva na značaju u vremenu krize izazvane pandemijom bolesti COVID-19. Poduzetnici su generatori ekonomskog rasta, zaposlenosti i stvaranja vrijednosti. Pokretani inovacijama i kreativnošću jedni su od nositelja društvenih promjena. Upravo zbog svog utjecaja na gospodarstvo,

\footnotetext{
* doc. dr. sc. Mladen Turuk, Ekonomski fakultet, Sveučilište u Zagrebu, mturuk@efzg.hr

** izv. prof. dr. sc. Bojan Morić Milovanović, Institut za javne financije, bojan.moric@ijf.hr

***Tihana Galić, struc. spec. oec. Ekonomski fakultet Sveučilišta u Zagrebu, tihanagalic1@gmail.com
} 
razumijevanje što motivira poduzetnike od podjednakog je teorijskog i praktičkog značaja. Pored tradicionalnog poduzetništva koje se promatra primarno kroz mala $\mathrm{i}$ srednja poduzeća moguće je razlučiti i faktore motivacije kod korporativnih poduzetnika. Korporativni poduzetnici ili intrapoduzetnici koji oko sebe okupljaju najkvalitetnije pojedince iz raznih funkcijskih područja unutar poduzeća, s ciljem nastanka i razvoja novih ideja nositelji su poduzetničkih aktivnosti unutar velikih poduzeća (Kolaković i Mikić, 2020). Tradicionalno i korporativno poduzetništvo krase mnoge zajedničke karakteristike, od kojih su neke usredotočenost na inovacije, usredotočenost na kreiranje proizvoda koji stvaraju dodanu vrijednost i potrebitost investiranja u rizične aktivnosti, odnosno aktivnosti s neizvjesnim ishodom (Škrtić i Mikić, 2011).

Poduzetnička motivacija proces je koji stimulira željeno ponašanje kod poduzetnika u ostvarivanju njegovih individualnih i organizacijskih ciljeva. Stoga je cilj ovoga istraživanja odgovoriti na istraživačko pitanje „postoje li razlike u motivacijskim čimbenicima između poduzetnika i intrapoduzentika te ako da, koje su to razlike," odnosno istražiti ekstrizične i intrizične čimbenike motivacije. Kako bi se istražio utjecaj motivacijskih čimbenika u teorijskom pregledu literature pružen je pregled najznačajnijih teorija motivacije.

Rad je podijeljen u pet cjelina. Nakon uvodnog dijela rada u kojem su prikazani ciljevi i svrha rada, u drugome dijelu navodi se pregled literature te se pojmovno određuju značajke poduzetništva, poduzetnika i intrapoduzetnika. U tom se poglavlju navode teorijske ekstrizične i intrizične odrednice motivacije prikazane kroz sadržajne teorije motivacije. Treći dio rada odnosi se na istraživačku metodologiju te se navodi prikaz metode prikupljanja podataka i ispitanika koji su sudjelovali u kvalitativnom istraživanju. $U$ četvrtom je dijelu rada provedena analiza dobivenih rezultata s posebnim osvrtom na ekstrizične i intrizične čimbenike motivacije. Zaključna razmatranja predstavljaju peti, posljednji dio rada u kojem su rezimirane najvažnije spoznaje do kojih se došlo prilikom izrade rada.

\section{Pregled literature}

\subsection{Teorijske odrednice poduzetnika i intrapoduzetnika}

Razvoj poduzetništva rastući je fenomen u današnjem globaliziranom svijetu. Posebno se ističe uloga malih i srednjih poduzeća koja u razvijenim tržišnim gospodarstvima u pravilu u ukupnom broju poduzeća sudjeluju s više od $95 \%$ te zapošljavaju oko 60 \% raspoložive radne snage. U Europskoj uniji mala i srednja poduzeća čine $99 \%$ svih poduzeća te zapošljavaju više od sto milijuna ljudi. Trenutačno je u središtu Europske komisije Strategija malih i srednjih poduzeća za održivu i digitalnu Europu s ciljem povećanja broja malih i srednjih poduzeća koja sudjeluju u održivim poslov- 
nim praksama, kao i povećanja broja poduzeća koja implementiraju digitalne tehnologije. Konačno, cilj same strategije je da Europa postane atraktivno mjesto za pokretanje i rast poduzeća na jedinstvenom tržištu EU-a i šire (Europska komisija, 2020). Samo poduzetništvo usko je korelirano s pojmovima inovacija i kreacija, odnosno povećanjem konkurentnosti te predstavlja ključnu silu u suzbijanju siromaštva i stvaranju radnih mjesta (Amornpinyo, 2018).

Promatrajući osnovne karakteristike poduzetnika, McClelland (1987) je u svojem istraživanju istaknuo šest osobina koje definiraju uspješnog poduzetnika, a to su inovativnost, razumno preuzimanje rizika, uporan rad, postavljanje ciljeva, odgovornost te samouvjerenost. Amornpinyo (2018) smatra da uspješni poduzetnici trebaju biti poslovno orijentirani, sposobni prikupljati i procesuirati poslovne informacije kako bi modificirali svoje poslovne strategije, fleksibilni, inovativni te imati razvijen osjećaj društvene odgovornosti. S druge strane, pored osobnih karakteristika, Turan i Kara (2007) proučavali su varijable kao što su religija, politika, umrežavanje i ideologija te su promatrali njihov utjecaj na razvoj poduzetništva. Također, Sarri i Trihopoulou (2005) te Mersha i Sriram (2019) istraživali su utjecaj roda na razvoj poduzetništa te razlike u rodnoj pripadnosti u poduzetničkom kontekstu.

Osim tradicionalno proučavanog poduzetništva kroz mala i srednja poduzeća, poduzetništvo je moguće promatrati u korporativnom okruženju. Razumijevajući što motivira poduzetnike i intrapoduzetnike od kritičnog je značaja za stvaranje novih poduzeća i poslovnih pothvata. Carsrud i Brännback (2011) navode da je upravo motivacija veza između poduzetničke namjere i poduzetničke akcije te da postoji veza između motivacije i poslovnog uspjeha. Motivirajući čimbenici također se mogu klasificirati kao faktori potiska ili privlačenja (Delmar i Davidsson, 2000). „Čimbenici potiska uključuju potrebu za povećanjem obiteljskih prihoda, nezadovoljstvo poslom koji se temelji na plaći, probleme s pronalaženjem odgovarajućeg posla i potrebu za fleksibilnošću za obiteljske obveze. Čimbenici privlačenja uključuju potrebu za neovisnošću, samoaktualizacijom, povećanjem statusa quo i ugledom u društvu" (Yalcin i Kapu, 2008: 188-189).

Korporativno poduzetništvo ili intrapoduzetništvo kao pojam odnosi se na implementaciju i provođenje poduzetničkih aktivnosti unutar velikih poduzeća (Morić Milovanović, 2009; De Villiers-Scheepers, 2011; Kuratko, 2017). Taj oblik poduzetničkog djelovanja pojavio se osamdesetih godina prošloga stoljeća (Morić Milovanović, 2009; Kuratko, 2017) te se može odnositi na razvoj i implementaciju novih ideja te raznih oblika inovacija, kao što su razvoj novih proizvoda i usluga, modifikacija administrativnih procedura te unapređenje proizvodnih procesa (Morić Milovanović, 2009; Bager et al., 2010). Morić Milovanović et al. (2016) promatraju korporativno poduzetništvo kao izazov tradicionalnim velikim poduzećima kroz prizmu osnovnih dimenzija poduzetničke orijentacije, tj. kroz koncepte inovativnosti, proaktivnosti te sklonosti riziku (Galetic i Morić Milovanović, 2008; Bager, 2010). Prema tim autorima poduzetnički nastrojena 
poduzeća su ona čije strateško djelovanje sadrži dimenzije poduzetničke orijentacije. Također, Kolaković et al. (2008) smatraju da se korporativno poduzetništvo može promatrati i kroz manifestaciju realizacije poduzetničkih aktivnosti, kao što su kreiranje novih poslovnih poduhvata te razvoj inovacije proizvoda, usluga i procesa, a što podrazumijeva motivaciju i htijenje zaposlenika (Hisrich i Kearney, 2012; Kuratko, 2017).

Kao što je poduzetnik nositelj poduzetničkog djelovanja u malim i srednjim poduzećima, tako je intrapoduzetnik ili korporativni poduzetnik nositelj poduzetničkog djelovanja u velikim poduzećima, odnosno velikim gospodarskim sustavima (Camelo-Ordaz et al., 2012; Mohedano-Suanes i Benítez, 2018). Nadalje, baš kao što postoje karakteristična obilježja koja krase poduzetnike, tako postoje i karakteristična obilježja intrapoduzetnika (Bager et al., 2010; De Villiers-Scheepers, 2011). Kolaković et al. (2008) gledaju na intrapoduzetnike kao na šampione/prvake unutar korporacije koji su u stanju uspješno pretvoriti svoje ideje u dodanu vrijednost, pri čemu oni sami ne moraju nužno biti ti koji su inicijalno osmislili ideju. Intrapoduzetnik je u svojoj osnovi interno motivirani vizionar sa snažnim osjećajem razumijevanja strateške orijentacije poduzeća (Mohedano-Suanes i Benítez, 2018). Intrapoduzetnik pokazuje mnoge od istih osobina koje definiraju dobrog vođu: vizija, snažna intrinzična motivacija, spremnost na preuzimanje rizika, sposobnost prikupljanja resursa te povijest realizacije postavljenih ciljeva (Camelo-Ordaz et al., 2012; Kuratko, 2017). Također, intrapoduzetnik treba posjedovati i određene kompetencije karakteristične tradicionalnim menadžerima, kao što su socijalne vještine, sposobnost rada u timovima te sposobnost umrežavanja, zato što su te osobine izuzetno važne za upravljanje procesima unutar organizacije (De Villiers-Scheepers, 2011; Camelo-Ordaz et al., 2012). Nužno je navesti osnovnu razliku između poduzetničkog i intrapoduzetničkog djelovanja koja se odnosi na rizik korištenja resursa zato što intrapoduzetnici donose rizične odluke koristeći se resursima poduzeća u kojem su zaposleni, dok poduzetnici koriste vlastite resurse što dodatno pojačava „strah” od donošenja pogrešne poslovne odluke (Bager et al., 2010; Mohedano-Suanes i Benítez, 2018). Zaključno, intrapoduzetnici kontinuirano nastoje unaprijediti poslovanje transformacijom svakodnevnih operativnih aktivnosti u inovacije unutar postojeće organizacijske strukture pri čemu iskazuju vrlo visoku razinu motiviranost (De Villiers-Scheepers, 2011; Srhoj i Morić Milovanović, 2016; Kuratko, 2017).

\subsection{Teorijske odrednice motivacije}

Brojni znanstvenici proučavali su motivaciju kao psihološki proces koji pojedinca potiče na usvajanje navika, znanja, vještina i sposobnosti (Pardee, 1990; Sachau, 2007; Alfayad i Arif, 2017; Khanna, 2017; Dohlman et al., 2019; Mansaray, 2019; Schunk i DiBenedetto, 2020; Acquah et al., 2021). Istraživanja motivacije su kompleksna jer se radi o psihološkim procesima i zato što motivacijski intenzitet ovisi o pojedincu 
(Pardee, 1990; Jambrek i Penić, 2008). U najužem smislu, motivacija se može objasniti kao poticaj za ostvarivanje nekog cilja, pri čemu motivacija zahtjeva ulaganja kao što su intelekt, upornost i koncentracija koji direktno ili indirektno utječu na kvalitetu i kvantitetu stečenog znanja (Alfayad i Arif, 2017). U literaturi je moguće pronaći razne čimbenike motivacije, kao što su energija i napor, postojanje unutarnjih i/ili vanjskih zapreka i obrambenih mehanizama, stečene radne navike, organizacijske sposobnosti i druge okolnosti koje različitim intenzitetom utječu na usvajanje novih znanja (Pardee, 1990; Alfayad i Arif, 2017). Nadalje, literatura navodi (Mijoč, 2019) kako se brojne teorije motivacije u osnovi mogu razvrstati u dvije osnovne skupine koje se razlikuju po svom viđenju osnova i uzroka ponašanja, a to su sadržajne i procesne teorije motivacije.

Sadržajne teorije motivacije bazirane su na identifikaciji te klasifikaciji potreba koje pojedinca potiču na određeno djelovanje (Mansaray, 2019). Najznačajnije sadržajne teorije motivacije su: (a) teorija hijerarhije potreba, (b) teorija trostupanjske hijerarhije, (c) teorija motivacije postignuća te (d) dvofaktorska teorija motivacije (Pardee, 1990; Alfayad i Arif, 2017). Procesne teorije motivacije smatraju da koncept potreba nije dovoljan, već da je potrebno uključiti i druge varijable kao što su očekivanja, percepcija, vrijednosti te njihove interakcije (Khanna, 2017; Schunk i DiBenedetto, 2020). Procesne teorije motivacije pružaju objašnjenja zašto se zaposlenici u određenim radnim situacijama ponašaju na način na koji se ponašaju (Hattie et al., 2020). Također, te teorije nazivaju se i kognitivnim teorijama zbog pretpostavke svjesnog izbora alternativnog ponašanja (Schunk i DiBenedetto, 2020). Najznačajnije procesne teorije motivacije su: (a) kognitivni model motivacije, (b) teorija privlačnosti u socijalnoj razmjeni, (c) integrativni procesni model motivacije te (d) složenost motivacije za rad (Mansaray, 2019; Schunk i DiBenedetto, 2020; Hattie et al., 2020). U nastavku će detaljnije biti prikazane isključivo sadržajne teorije motivacije zato što su one korištene kao teorijska osnova za potrebe ovog istraživanja.

\subsubsection{Teorija potreba: Maslowljeva hijerarhija potreba}

Teorija potreba, tj. Maslowljeva hijerarhija potreba (Maslow, 1943; Dohlman, 2019) smatra se jednim od najznačajnijih istraživanja ponašanja zaposlenika te se još uvijek smatra jednom od najutjecajnijih teorija iz tog područja. Teorija potreba polazi od specifičnih potreba i njihovih zadovoljavanja kao osnove za ravnotežu i opstanak ljudskog organizma te pruža objašnjenje zbog čega ljudi reagiraju na način na koji reagiraju te da postoji specifičan redoslijed razvoja potreba i to na način da se više rangirane potrebe ne mogu izraziti sve dok prije toga niže rangirane potrebe nisu zadovoljene (Mansaray, 2019; Acquah et al., 2021). Drugim riječima, kada se jedan skup potreba zadovolji, tada ta vrsta potreba prestaje biti motivator. Navodimo redoslijed potreba prema Maslowu (Lazibat i Dumičić, 2002; Jambrek i Penić, 2008). 
1. Fiziološke potrebe (primarne biološke potrebe), odnosno osnove potrebe za održavanje ljudskog života/ljudske egzistencije, a čine ih hrana, voda, toplina, stanovanje itd. Maslow smatra da sve dok te osnovne potrebe nisu zadovoljene, čovjek ne može biti motiviran drugim potrebama.

2. Potrebe za sigurnošću, odnosno potreba za redom, poretkom te strukturom kao što su želja za stalnim poslom, stjecanjem imovine itd. Potreba za sigurnošću također se vezuje i za nepredvidive opasnosti poput rata, prirodnih katastrofa, bolesti i kriminala.

3. Potrebe za povezivanjem ili prihvaćanjem, odnosno potreba za ljubavi koju Maslow smatra osnovnim uvjetom za zdrav razvoj pojedinca, a tu potrebu objašnjava kao odnos međusobnog poštovanja i povjerenja.

4. Potreba za poštovanjem veže se za potrebu povezivanja i prihvaćanja, odnosno kada pojedinac razvije povezanost s drugom osobom, tada u tom odnosu traži i poštovanje, pri čemu je nužno istaknuti da pojedinac mora imati i razvijeno samopoštovanje. Iz te vrste potreba razvile su se potrebe za statusom, utjecajem i hijerarhijom.

5. Potreba za samoaktualizacijom, odnosno samopotvrđivanjem. Maslow upravo tu potrebu smatra najvišom potrebom u svojoj hijerarhiji jer ona predstavlja maksimizaciju nečijeg potencijala.

\subsubsection{Teorija trostupanjske hijerarhije}

Mnogi autori probali su modificirati Maslowljevu hijerarhiju potreba, ali najznačajniju alternativu dao je Alderfer (1969) nazvavši je trostupanjska hijerarhija potreba (Acquah et al., 2021). Teoriju trostupanjske hijerarhije čine tri kategorije potreba: (a) potrebe egzistencije, (b) potrebe povezanosti te (c) potrebe rasta i razvoja (Acquah et al., 2021). Potrebe za egzistencijom definiraju se kao različiti oblici materijalnih i fizioloških želja, kao što su nadnica, razni materijalni dobici, beneficije te uvjeti rada. Potrebe povezanosti smatraju se društvenim potrebama a vežu se za one odnose koje pojedinac smatra relevantnima, kao što su obitelj, prijatelji, suradnici, nadređeni itd. (Mansaray, 2019). Potrebe rasta i razvoja definiraju se kao potrebe proizašle iz kreativnog i produktivnog djelovanja pojedinca kako na sebe tako i na njegovu okolinu. Temelj navedenih potreba odnosi se na razvijanje potencijala pojedinaca, odnosno rješavanje problema koji će pojedinca potaknuti da maksimalno iskoristi svoje potencijale (Acquah et al., 2021).

\subsubsection{Motivacijska teorija potreba: McClellandova teorija}

McClellandova motivacijska teorija promatra što pojedinac zapravo želi, a ne ono što je potrebno za njegov opstanak (Mansaray, 2019); Acquah et al., 2021). Prema McClellandu (2005) postoje tri tipa motivirajućih potreba. Prva je potreba za postignućem i ona pripada pojedincima koji imaju izrazitu željom za uspjehom. Druga potreba je 
moć i bazira se na kontroli i utjecaju jednog pojedinca na druge. Treća potreba je povezanost, odnosno pojedinac će biti sretan samo kada je voljen i sretan. Pristup motivaciji je definiran kroz nekoliko dimenzija: (a) usmjeren na motivaciju za rad, (b) pojedinačni motiv definiran kao temelj radnog ponašanja, (c) potrebe i motivi koji se uzimaju za osnovu ponašanja su stečeni, odnosno rezultat su učenja ili socijalizacije, (d) intrinzična motivacija (Pardee, 1990; Lazibat i Dumičić, 2002; McClelland, 2005; Mijoč, 2019).

\subsubsection{Herzbergova dvofaktorska teorija}

Dvofaktorska teorija motivacije naziva se još i dvojna teorija motivacije (Pardee, 1990; Lazibat i Dumičić, 2002; Sachau, 2007). Za razliku od prethodno navedenih teorija, dvofaktorska teorija motivacije ne promatra isključivo potrebe, već se fokusira na radnu situaciju te na klasifikaciju čimbenika za rad, pri čemu se čimbenik rada mjeri stupnjem zadovoljstva poslom (Sachau, 2007). Herzbergova teorija sastoji se od dviju osnovnih dimenzija pri čemu se promatra stupanj zadovoljstva ili nezadovoljstva motivacijskim čimbenikom (Acquah et al., 2021). Prva dimenzija odnosi se na ekstrinzične (vanjske) čimbenike, kao što su novčane nagrade, uvjeti rada, status itd., dok se druga dimenzija odnosi na intrinzične (unutarnje) čimbenike, kao što su izazovnost posla, osjećaj uspjeha, samostalnost itd. (Sachau, 2007; Alfayad i Arif, 2017).

Promatrano detaljnije, ekstrinzičnu motivaciju možemo smatrati motivacijom uvjetovanom vanjskim poticajima, a veže se uz želju da izvršavanje određene aktivnosti bude „nagrađeno” pozitivnim posljedicama, odnosno da se izbjegnu negativne posljedice, poput primjerice kazne (Acquah et al., 2021). Ekstrinzična motivacija u osnovi se temelji na formalnim poticajima koji pojedincu omogućuje stjecanje neke vrste „opipljive” koristi, kao što su nagrade, stjecanje određenog statusa, napredovanja itd. te se može povećavati sustavnim nagrađivanjem pojedinca, odnosno pružanjem jasnih i učestalih povratnih informacija (Mansaray, 2019; Khanna, 2017). S druge strane, intrinzičnu motivaciju možemo promatrati kao unutarnju motivaciju, tj. sve ono što pojedinca iznutra motivira na provođenje odabranih aktivnosti te određuje njihov smjer, intenzitet i trajanje (Sachau, 2007; Khanna, 2017). Drugim riječima, svako ponašanje na koje djeluje vlastiti poticaj smatra se da je intrinzično motivirano ponašanje. Na intrinzičnu motivaciju može se gledati kao urođenu motivaciju odnosno instinkt da pojedinac slijedi vlastiti interes te zbog je toga voljan uložiti napor s ciljem daljnjeg osobnog razvoja (Mansaray, 2019). Stoga, poduzeća pored kreiranja sustava usmjerenih na ekstrinzične motivatore mogu također potaknuti kod pojedinaca i razvoj intrinzične motivacije, kao što su omogućavanje zaposlenicima rad na izazovnim poslovima ili zadacima s ciljem njihovog daljnjeg profesionalnog ili osobnog razvoja ili putem odavanja priznanja za njihov trud s ciljem individualnog osnaživanja (Sachau, 2007; Alfayad i Arif, 2017). 


\section{Metodologija istraživanja}

\subsection{Metoda prikupljanja podataka}

U svrhu empirijskog dijela istraživanja, odnosno prikupljanja primarnih podataka, korištena je metoda polustrukturiranog intervjua kao jednog od oblika kvalitativne metode istraživanja, pri čemu je za odabir ispitanika korištena metoda namjernog uzorka. Nadalje, za odabir uzorka ispitanika s ciljem pružanja odgovora na postavljeno istraživačko pitanje odlučeno je da se ispita jednak broj ispitanika iz obje promatrane skupine, tj. po četiri poduzetnika i četiri intrapoduzetnika. Svih osam intervjua provedeni su tehnikom licem u lice na području grada Zagreba unatoč raznim ograničenjima vezanim uz pandemiju COVID-19. Također, istraživanjem je zajamčena anonimnost ispitanika. Empirijsko istraživanje trajalo je u periodu od svibnja do srpnja 2021.

\subsection{Opis ispitanika i operacionalizacija istraživanja}

Pri odabiru ispitanika nastojalo se postići da ispitanici posluju u različitim djelatnostima te obnašaju različite funkcije kako bi se dobila šira perspektiva razlika u motivaciji između poduzetnika i intrapoduzetnika. Ispitanici su klasificirani oznakom $\mathrm{P}$ za poduzetnika te oznakom I za intrapoduzetnika. Detaljan opis osnovnih karakteristika ispitanika pružen je u nastavku teksta, dok tablica 1 pruža detaljan pregled operacionalizacije istraživanja.

— Ispitanik P1 je vlasnik poduzeća koje se bavi trgovinom na veliko. Ispitanik P1 godinama je stjecao poslovno iskustvo poslujući u inozemstvu što mu je pružilo širu sliku samog poslovanja te na kraju pridonijelo uspješnom razvoju vlastitog poduzeća koje trenutačno posluje u Hrvatskoj i u inozemstvu.

- Ispitanik P2 je vlasnik obiteljskog poduzeća koje se bavi trgovinom na malo te jako dobro posluje već trideset godina. Ispitanik P2 ističe važnost postojanja intrapoduzetnika u organizaciji, pri čemu je u njegovom poduzeću razvijen sustav poticanja, motiviranja te nagrađivanja onih zaposlenika koji pokazuju intrapoduzetničke sklonosti.

- Ispitanik P3 je vlasnik poduzeća za računalno programiranje usmjereno na pružanje informatičke podrške javno-zdravstvenim institucijama. Ispitanik P3 je u poduzetništvu već dvanaest godina te je svjestan raznih vanjskih i unutarnjih čimbenika koji utječu na njegovo poslovanje.

- Ispitanik P4 je vlasnik agencije za zapošljavanje i posredovanje pri zapošljavanju, pri čemu zadnjih nekoliko godina značajan udio poslovanja predstavlja suradnja sa sličnim inozemnim agencijama s ciljem popunjavanja deficitarnih radnih 
mjesta u Hrvatskoj sa stranom radnom snagom. Ispitanik P4 također navodi kako intrapoduzetništvo predstavlja značajnu odrednicu uspješnosti poduzeća.

- Ispitanik I1 je direktor maloprodaje u djelatnosti novčarskog posredovanja, pri čemu svoju ulogu intrapoduzetnika obnaša već desetu godinu. Također, u slobodno vrijeme bavi se poduzetništvom u turizmu. Ispitanik I1 predstavlja izvrstan odabir ispitanika ovog istraživanja zato što jako dobro poznaje svijet poduzetništva i korporativnog poduzetništva, a samim time ulogu i značaj intrinzičnih i ekstrinzičnih čimbenika motivacije u poslovanju.

- Ispitanik I2 je voditelj prodaje u agenciji za zapošljavanje i posredovanje pri zapošljavanju, koji svakodnevno generira ideje vezanih uz unapređenje poslovnih procesa.

- Ispitanik I3 je voditelj odjela investicijskog bankarstva pri čemu trenutnu poziciju obnaša već deset godina te svakodnevno nastoji pretvarati svoje ideje u dodanu vrijednost za poduzeće. Također, nužno je napomenuti kako stupanj motivacije i liderskog duha ispitanika I3 predstavlja ogledni primjer intrapoduzetništva.

- Ispitanik I4 je direktor financija i član uprave društva u industriji proizvodnje uređaja za dizanje i prenošenje, pri čemu je svoje dugogodišnje iskustvo rada u reviziji u zadnje četiri godine zamijenio novom industrijom i navedenim novim radnim mjestom. Velika želja ispitanika I4 bila je vidjeti poslovanje iz druge perspektive, odnosno želio je svoje iskustvo rada u reviziji prenijeti i primijeniti u korporativnom okruženju.

Tablica 1. Pregled osnovnih informacija provedenih intervjua

\begin{tabular}{|c|c|c|c|c|}
\hline Datum & Ispitanik & Funkcija & Djelatnost & Trajanje \\
\hline 27. 5. 2021. & P1: poduzetnik & vlasnik poduzeća & $\begin{array}{l}\text { nespecijalizirana trgovina na } \\
\text { veliko }\end{array}$ & $30 \mathrm{~min}$ \\
\hline 28. 5. 2021. & P2: poduzetnik & vlasnik poduzeća & $\begin{array}{c}\text { specijalizirana trgovina na } \\
\text { malo }\end{array}$ & $30 \mathrm{~min}$ \\
\hline 28. 5. 2021. & I1: intrapoduzetnik & $\begin{array}{c}\text { direktor sektora } \\
\text { maloprodaje }\end{array}$ & novčarsko posredovanje & $40 \mathrm{~min}$ \\
\hline 31. 5. 2021. & P3: poduzetnik & vlasnik poduzeća & računalno programiranje & $30 \mathrm{~min}$ \\
\hline 31. 5. 2021. & I2: intrapoduzetnik & voditelj prodaje & $\begin{array}{c}\text { agencija za privremeno } \\
\text { zapošljavanje }\end{array}$ & $30 \mathrm{~min}$ \\
\hline 31. 5. 2021. & P4: poduzetnik & vlasnik poduzeća & $\begin{array}{c}\text { agencija za privremeno } \\
\text { zapošljavanje }\end{array}$ & $30 \mathrm{~min}$ \\
\hline 1. 6.2021. & I3: intrapoduzetnik & $\begin{array}{c}\text { voditelj investicijskog } \\
\text { bankarstva }\end{array}$ & investicijsko bankarstvo & $30 \mathrm{~min}$ \\
\hline 6. 6. 2021. & 14: intrapoduzetnik & direktor financija & $\begin{array}{l}\text { proizvodnja uređaja za dizanje } \\
\text { i prenošenje }\end{array}$ & $30 \mathrm{~min}$ \\
\hline
\end{tabular}

Izvor: autori. 


\subsection{Analiza podataka}

Analiza prikupljenih primarnih podataka rađena je u nekoliko koraka, pri čemu je prvi korak u obradi primarnih podataka bila transkripcija provedenih intervjua. To je dovelo do smanjenja broja podataka kako bi se omogućilo jasnije razumijevanje odgovora na temelju kojih se mogu donositi zaključci. Nakon transkripcije te podjele podataka na kategorije provedeno je sumiranje podataka u jasne rezultate. Nadalje, tijekom postupka kodiranja uklonjeni su podaci za koje je zaključeno da nisu relevantni ili da nisu striktno povezani s pružanjem odgovora na istraživačko pitanje. Kodiranjem podataka dobivena su četiri koda: a) intrinzični motivacijski faktori poduzetnika, b) ekstrinzični motivacijski faktori poduzetnika, c) intrinzični motivacijski faktori intrapoduzetnika, d) ekstrinzični motivacijski faktori intrapoduzetnika koji su detaljno objašnjeni u nastavku teksta.

\section{Rezultati istraživanja}

\subsection{Analiza ekstrinzičnih čimbenika motivacije}

Analizom prikupljenih podataka od ispitanika, u nastavku teksta pružen je sažetak osnovnih zaključaka o razlikama u motivacijskim čimbenicima između poduzetnika i intrapoduzetnika, a koji se odnose na novčane nagrade, izazov te trening i edukaciju kao oblika ekstrinzične motivacije. Također, tablica 2 pruža sažet prikaz ekstrinzičnih čimbenika motivacije koji su klasificirani sukladno prikupljenim odgovorima ispitanika.

- Novčana nagrada

Analizom empirijskih podataka ustanovljeno je da većina poduzetnika smatra da su novčane nagrade odnosno financijska stabilnost poslovanja iznimno važna odrednica njihovog poslovanja. Iako novčane nagrade možda nisu isključivi i osnovni motivacijski čimbenik poduzetnika, međutim svakako predstavljaju neophodan čimbenik zbog kojeg su poduzetnici voljni razvijati svoje poslovanje. S druge strane, intrapoduzetnici smatraju kako novčane nagrada ne predstavljaju osnovni motivacijski čimbenik u provođenju poslovnih aktivnosti.

- Izazov

Poduzetnici smatraju da izazovne situacije s kojima se susreću u poslovanju djeluju vrlo motivirajuće. Također, naglašavaju da im izazovi sami po sebi ne predstavljaju u toliko mjeri motivaciju, koliko suočavanje s izazovom i pronalaženje rješenja. Nužno je istaknuti kako ni jedan od ispitanih poduzetnika nije posustao u izazovnim i rizičnim situacijama, već na izazov gledaju kao na nešto što ih potiče da se izbore za opstanak svog poslovanja. S druge strane, intrapoduzetnici imaju nešto drugači- 
ji pogled na izazov. Nekima izazov nije osobito motivirajući čimbenik, dok drugima predstavlja značajan čimbenik koji ih motivira da ustraju u razvoju svog projekta. Intrapoduzetnici smatraju da izazov djeluje motivirajuće jer pruža priliku da se iskušaju vlastita znanja i vještine. Također, intrapoduzetnici gledaju na izazov kroz prizmu kvalitetnog upravljanja velikim brojem zaposlenika te pridržavanja etičnosti i etičnih načela u današnjem poslovanju.

- Trening i edukacija

Poduzetnici smatraju da mogućnost poslovnog i osobnog rasta, razvoja te učenja novih vještina predstavlja značajan indirektan motivacijski čimbenik. Ispitani poduzetnici gledaju na trening kao proces cjeloživotnog učenja te smatraju da je ono vrlo bitno u razvojnom procesu pojedinca. Također, ispitani poduzetnici smatraju da su na taj način usvojili razne vještine koje im pomažu umanjiti rizik poslovanja te povećati profitabilnost. Većina ispitanika na trening ne gleda kao na iznimno važan motivacijski čimbenik, međutim slažu se kako je on iznimno važan u procesu učenja i razvoja koji indirektno vodi ka višoj razini motivacije. S druge strane, ispitani intrapoduzetnici smatraju da svako ulaganje poslodavca u nihov razvoj i rast predstavlja korist koju svakako treba iskoristiti. Intrapoduzetnici naglašavaju da su tijekom svog radnog vijeka iskusili samo koristi u obavljanju svojih radnih zadataka nakon pohađanja neke vrste treninga odnosno edukacije. Također, intrapoduzetnici smatraju da je trening dobra motivacija zato što poduzeće na taj način pojedincu daje do znanja da cijeni njego trud te da računa na njegov doprinos i u budućnosti. Svakako je vrlo važno napomenuti da određeni ispitanici smatraju da se puno više može naučiti iz iskustva nego isključivo iz treninga.

Tablica 2. Ekstrinzični čimbenici motivacije prikupljeni od ispitanika

\begin{tabular}{|c|c|c|}
\hline Čimbenici & Poduzetnici & Intrapoduzetnici \\
\hline $\begin{array}{l}\text { Novčana } \\
\text { nagrada }\end{array}$ & $\begin{array}{l}\text { - nije glavni motiv } \\
\text { - vrsta pokretača } \\
\text { - potreba za egzistencijom }\end{array}$ & $\begin{array}{l}\text { - potreba za egzistencijom } \\
\text { - nije glavni motiv } \\
\text { - vjetar u leđa } \\
\text { - dovodi do ispunjena cilja }\end{array}$ \\
\hline Izazov & $\begin{array}{l}\text { - prilika za iskušati svoja znanje i } \\
\text { vještine } \\
\text { - suočavanje s rizikom } \\
\text { - razni vanjski i unutarnji problemi } \\
\text { (COVID-19, lockdown, potres, } \\
\text { financijska kriza itd.) }\end{array}$ & $\begin{array}{l}\text { - nastavak i opstanak rada } \\
\text { - koordinacija velikog broja ljudi } \\
\text { - rješavanje problema unutar tima }\end{array}$ \\
\hline Trening & $\begin{array}{l}\text { - pomaže u ostvarenju cilja } \\
\text { - ulaganje u znanje i vještine } \\
\text { - pomaže u suočavanju s rizikom }\end{array}$ & $\begin{array}{l}\text { - osjećaj pripadnosti organizaciji } \\
\text { - rad na sebi pridonosi organizaciji }\end{array}$ \\
\hline
\end{tabular}

Izvor: autori. 


\subsection{Analiza intrinzičnih čimbenika motivacije}

U ovome dijelu prikazuje se sažetak osnovnih zaključaka o razlikama u motivacijskim čimbenicima između poduzetnika i intrapoduzetnika, a koji se odnose na moć, pripadnost te priznanje kao oblike intrinzične motivacije. Tablica 3 pruža sažet prikaz intrinzičnih čimbenika motivacije koji su klasificirani sukladno prikupljenim odgovorima ispitanika.

- Moć

Tijekom provedenih razgovora svi ispitani poduzetnici istaknuli su moć kao jedan od osnovnih motivacijskih čimbenika. Međutim, nužno je napomenuti da na moć ne gledaju u negativnom kontekstu, već kao na osjećaj kontrole nad organizacijskim procesima i zaposlenicima te kao osjećaj slobode da mogu donositi odluke koje dovode do pozitivnih promjena. S druge strane, intrapoduzetnici moć promatraju kroz prizmu proaktivnog djelovanja pri čemu oni trebaju biti uzor drugima kako bi ih ostali slijedili. Oni vodstvo smatraju izrazito bitnim zato što se na taj način prenosi motivacija na ostale zaposlenike. Cilj intrapoduzetnika je nadzirati, kontrolirati i voditi zaposlenike kako bi na taj način njihova moć došla do izražaja.

- Pripadnost

Ispitani poduzetnici ne smatraju pripadnost osnovnom motivacijom, već im je bitno da kroz osjećaj pripadnosti svi zaposlenici zajednički rade za ostvarenje istih ciljeva, tj. važno im je postizanje homogenosti tima. S druge strane, ispitani intrapoduzetnici smatraju da osjećaj pripadnosti organizaciji ili timu predstavlja značajnu motivaciju. Odnosno, ističu da pored vještina i znanja, intrapoduzetnik mora moći razviti kolegijalan odnos sa svojim timom.

\section{- Priznanje}

Ispitani poduzetnici naglasili su da priznanje za njih predstavlja iznimni motivacijski čimbenik zato što im priznanje koje dobiju od drugih (u najširem smislu riječi) daje poticaj za nastavak rada i za suočavanje s novim budućim izazovima. Ispitani intrapoduzetnici promatraju priznanje kroz prizmu postignuća te smatraju da je ono vrlo važno zato što se bez uspjeha unutar organizacije i realizacije poslovnih ciljeva ne može postići potrebna razina motivacije. Intrapoduzetnici gledaju na uspjehe svojih kolega kao važan oblik motivacije te smatraju da su programi obuke i treninga iznimno bitni kako bi intrapoduzetnici bili u mogućnosti steći što kvalitetnija znanja i vještine, a samim time si i olakšali put do uspjeha. 
Tablica 3. Intrinzični čimbenici motivacije prikupljeni od ispitanika

\begin{tabular}{|c|c|c|}
\hline Čimbenici & Poduzetnici & Intrapoduzetnici \\
\hline moć & $\begin{array}{l}\text { - kontroliranje procesa i poslovanja } \\
\text { - kontrola nad samim sobom } \\
\text { - sloboda donošenja odluka }\end{array}$ & $\begin{array}{l}\text { - utjecati na druge } \\
\text { - biti vođa kada je potrebno } \\
\text { - kontroliranje procesa }\end{array}$ \\
\hline pripadnost & $\begin{array}{l}\text { - stjecati zajedno } \\
\text { - imati isti cilj }\end{array}$ & $\begin{array}{l}\text { - stvarati zajedno } \\
\text { - biti dio tima }\end{array}$ \\
\hline priznanje & $\begin{array}{l}\text { - stvarati novo } \\
\text { - samoaktualizacija }\end{array}$ & $\begin{array}{l}\text { - stvaranje rezultata } \\
\text { - dovršavanje projekata } \\
\text { - stvarati novo }\end{array}$ \\
\hline
\end{tabular}

Izvor: autori.

\section{Zaključna razmatranja}

Svrha istraživanja bila je steći dublje razumijevanje motivacijskih razlika između poduzetnika i intrapoduzetnika, pri čemu su se prvenstveno promatrale razlike u njihovim intrinzičnim i ekstrinzičnim čimbenicima motivacije. Provođenjem kvalitativnog istraživanja metodom polustrukturiranog intervjua pronađeni su sljedeći rezultati. Promatrajući ekstrinzične čimbenike motivacije ispitani poduzetnici motiviraniji su novčanim nagradama u odnosu na ispitane intrapoduzetnike, pri čemu se kao pretpostavku tog rezultata uzima veću ovisnost poduzetnika o poslovnom uspjehu vlastitog poduzeća. Kad je riječ o treningu i edukaciji kao oblicima ekstrinzične motivacije, gotovo podjednako poduzetnici i intrapoduzetnici ih ne smatraju iznimno značajnim motivatorom, pri čemu je nužno istaknuti kako intrapoduzetnici ipak stavljaju veći naglasak u odnosu na poduzetnike zato što se osjećaju vrijednima i podržanima u svojim organizacijama. Što se tiče intrinzičnih čimbenika motivacije, istraživanje je ukazalo da moć predstavlja značajniji motivacijski čimbenik za poduzetnike nego za intrapoduzetnike. Nadalje, priznanje također predstavlja značajan motivator za poduzetnike, dok za intrapoduzetnike ono ovisi o hijerarhijskoj razini koju zaposlenik ima unutar poduzeća te njegovoj razini znanja i iskustva. Zaključno, istraživanjem se potvrdilo postojanje razlike između ekstrinzičnih te intrinzičnih motivacijskih čimbenika među ispitanim poduzetnicima i intrapoduzetnicima. Rezultati su pokazali da su poduzetnici više motiviraniji novcem i moći u usporedbi s izazovom i priznanjem što predstavlja više motivirajuće čimbenike za intrapoduzetnike.

\subsection{Teoretske i menadžerske implikacije}

Radom je pružen sažet pregled najznačajnih teorija motivacije čime je pružena osnova daljnjeg izučavanja teoretskog okvira motivacijskih čimbenika. Također, pružen je 
sažet pregled razlika osnovnih karakteristika između poduzetnika i intrapoduzetnika te razlika u njihovim ekstrinzičnim i intrinzičnim motivacijskim čimbenicima što svakako može poslužiti vlasnicima poduzeća i menadžmentu prilikom formuliranja kadrovskih strategija i politika. Nadalje, u praktičnom smislu, rad naglašava ulogu i značaj novčanih nagrada, izazova, moći i priznanja kao osnovnih motivacijskih čimbenika za poduzetnike te s druge strane treninga i edukacije, moći, pripadnosti te priznanja kao osnovnih motivacijskih čimbenika za intrapoduzetnike.

\subsection{Ograničenja istraživanja i preporuke}

Zbog složenosti promatrane tematike te kompleksnosti operacionalizacije empirijskog istraživanja, u radu postoje brojna ograničenja. Prvenstveno, u procesu empirijskog dijela istraživanja ispitan je mali broj sudionika te bi buduća istraživanja trebala obuhvatiti znatno veći broj ispitanika kako bi se dobila jasnija i pouzdanija slika motivacijskih razlika između poduzetnika i intrapoduzetnika. Jedno od ograničenja moguće je pronaći i u specifičnom kontekstu u kojem je istraživanje provedeno, a koje je obilježeno pandemijom bolesti COVID-19 te još uvijek aktualnim posljedicama potresa u Zagrebu iz 2020. što je u konačnici moglo utjecati na perspektivu ispitanika u vezi s motivacijom. Također, potrebno je u istraživanje uključiti predstavnike iz različitih industrija s ciljem pokrivanja što većeg broja industrijskih grana. Nadalje, bilo bi dobro uključiti i menadžere raznih organizacijskih razina (operativna, srednja i strateška) kako bi se dobili kvalitetniji uvidi intrapoduzetnikove motivacije te kako bi se mogle razumjeti eventualne razlike s obzirom na poziciju radnog mjesta unutar organizacijske strukture. Također, bilo bi dobro istražiti utjecaj motivacijskih čimbenika na uspješnost poslovanja te pronaći eventualne razlike unutar specifičnog istraživačkog konteksta te posebice provesti istraživanje u dužem vremenskom periodu. 


\section{Literatura}

1. Acquah, A., Nsiah, T. K., Antie, E. N. A. i Otoo, B. 2021. Literature review on theories of motivation. EPRA International Journal of Economic and Business Review, 9 (5): 25-29.

2. Alderfer, C. P. 1969. An empirical test of a new theory of human needs. Organizational behavior and human performance, 4 (2): 142-175.

3. Alfayad, Z. i Arif, L. S. M. 2017. Employee voice and job satisfaction: An application of Herzberg two-factor theory. International Review of Management and Marketing, 7 (1): $150-156$.

4. Amornpinyo, N. 2018. The Characteristics of Entrepreneurs with Successful and Sustainable Small Businesses in Northeastern Thailand. Pertanika Journal of Social Sciences and Humanities, 26 (1): 113-128.

5. Bager, T., Ottosson, H. i Schott, T. 2010. Intrapreneurs, entrepreneurs and spin-off entrepreneurs: similarities and differences. International Journal of Entrepreneurship and Small Business, 10 (3): 339-358.

6. Camelo-Ordaz, C., Fernández-Alles, M., Ruiz-Navarro, J. i Sousa-Ginel, E. 2012. The intrapreneur and innovation in creative firms. International Small Business Journal, 30 (5): 513-535.

7. Carsrud, A. i Brännback, M. 2011. Entrepreneurial Motivations: What Do We Still Need to Know? Journal of Small Business Management, 49: 9-26.

8. De Villiers-Scheepers, M. J. 2011. Motivating intrapreneurs: the relevance of rewards. Industry and higher education, 25 (4): 249-263.

9. Delmar, F. i Davidsson, P. 2000. Where do they come from? Prevalence and characteristics of nascent entrepreneurs. Entrepreneurship and regional development, 12 (1): 1-23.

10. Dohlman, L., DiMeglio, M., Hajj, J. i Laudanski, K. 2019. Global Brain Drain: How Can the Maslow Theory of Motivation Improve Our Understanding of Physician Migration? International journal of environmental research and public health, 16 (7): 1182.

11. Europska komisija. 2020. Strategija za MSP-ove i održivu i digitalnu Europu. Bruxelles: 10. 3. 2020. COM (2020), 103 final.

12. Galetic, F. i Milovanović, B. M. 2008. Linking entrepreneurial orientation with the performance of Croatian hotel industry. An Enterprise Odyssey. International Conference Proceedings. University of Zagreb, Faculty of Economics and Business: 508.

13. Hattie, J., Hodis, F. A. i Kang, S. H. 2020. Theories of motivation: Integration and ways forward. Contemporary Educational Psychology, 61: 101865.

14. Hisrich, R. D. i Kearney, C. 2012. Corporate Entrepreneurship: How to Create a Thriving Entrepreneurial Spirit Throughout Your Company. New York: McGraw-Hill.

15. Jambrek, I. i Penić, I. I. 2008. Upravljanje ljudskim potencijalima u poduzećima - ljudski faktor, motivacija zaposlenika kao najvažniji čimbenici uspješnosti poslovanja poduzeća. Zbornik pravnog fakulteta Sveučilišta u Rijeci, 29 (2): 1181-1206.

16. Khanna, V. 2017. Measuring job satisfaction of academicians using Herzberg theory. Delhi Business Review, 18 (2): 75-86.

17. Kolaković, M. i Mikić, M. 2020. Poduzetništvo u 21. stoljeću. Zagreb: Studentski poduzetnički inkubator Sveučilišta u Zagrebu.

18. Kolaković, M., Sisek, B. i Morić Milovanović, B. 2008. Influence of corporate entrepreneurship on the performance of Croatian large companies. Global Business and Economics Anthology, Selected papers of 2008 Business and Economics Society International Conference. Lugano: 312-317. 
19. Kuratko, D. F. 2017. Corporate entrepreneurship 2.0: research development and future directions. Foundations and Trends in Entrepreneurship, 13 (6): 441-490.

20. Lazibat, T. i Dumičić, K. 2002. Upravljanje ljudskim resursima i permanentna izobrazba - temeljni čimbenici kvalitete. Zbornik, 4: 127-134.

21. Mansaray, H. E. 2019. The Role of Human Resource Management in Employee Motivation and Performance-An Overview. Budapest International Research and Critics Institute (BIRCI) Journal, 183-194.

22. Maslow, A. H. 1943. A Theory of Human Motivation. Psychological Review, 50: 370-396.

23. McClelland, D. 2005. Achievement motivation theory. Organizational behavior: Essential theories of motivation and leadership, 46-60.

24. McClelland, D. 1987. Characteristics of successful entrepreneurs. The Journal of Creative Behavior, 21 (3): 219-233.

25. Mersha, T. i Sriram, V. 2019. Gender, entrepreneurial characteristics, and success: Evidence from Ethiopia. Thunderbird International Business Review, 61 (2): 157-167.

26. Mijoč, J. 2019. Motivacija za postignućem u pojašnjenju namjera za samozapošljavanjem. Ekonomska misao i praksa, 1: 223-244.

27. Mohedano-Suanes, A. i Benítez, D. G. 2018. Intrapreneurs: Characteristics and behavior, u: In Inside the Mind of the Entrepreneur. Springer. Cham: 109-119.

28. Morić Milovanović, B. 2009. Sustav poticanja kao faktor razvoja korporativnog poduzetništva. Zbornik Ekonomskog fakulteta u Zagrebu, 7 (1): 189-202.

29. Morić Milovanović, B. 2009. Uloga menadžmenta u poticanju poduzetničkih aktivnosti velikih hrvatskih poduzeća. Poslovna izvrsnost, 3 (1): 25-44.

30. Morić Milovanović, B., Kunst, K. i Srhoj, S. 2016. Dijagnosticiranje poduzetničke klime-primjer poduzeća u farmaceutskoj industriji. Ekonomska misao i praksa, 1: 73-104.

31. Pardee, R. L. 1990. Motivation Theories of Maslow, Herzberg, McGregor and McClelland. A Literature Review of Selected Theories Dealing with Job Satisfaction and Motivation.

32. Sachau, D. A. 2007. Resurrecting the motivation-hygiene theory: Herzberg and the positive psychology movement. Human resource development review, 6 (4): 377-393.

33. Sarri, K. i Trihopoulou, A. 2005. Female entrepreneurs' personal characteristics and motivation: a review of the Greek situation. Women in Management Review, 20 (1): 24-36.

34. Schunk, D. H. i DiBenedetto, M. K. 2020. Motivation and social cognitive theory. Contemporary Educational Psychology, 60: 101832.

35. Srhoj, S. i Morić Milovanović, B. 2016. Dizajn razmišljanje kao suvremeni pristup rješavanju poslovnih problema. Zbornik Ekonomskog fakulteta u Zagrebu, 14 (2): 63-91.

36. Škrtić, M. i Mikić, M. 2011. Poduzetništvo. Zagreb: Sinergija.

37. Turan, M. i Kara, A. 2007. An exploratory study of characteristics and attributes of Turkish entrepreneurs: A cross-country comparison to Irish entrepreneurs. Journal of International Entrepreneurship, 5 (1-2): 25-46.

38. Yalcin, S. i Kapu, H. 2008. Entrepreneurial dimensions in transitional economies: A review of relevant literature and the case of Kyrgyzstan. Journal of Developmental Entrepreneurship, 13: 185-204. 


\title{
Comparative empirical analysis of extrinsic and intrinsic motivational factors between entrepreneurs and intrapreneurs
}

\begin{abstract}
Motivation is a factor that causes a certain desired behavior, where different factors determine the desired behavior in different types of observed economic entities. The aim of this paper is to gain a deeper understanding of the main differences in motivation between entrepreneurs and intrapreneurs. The paper provides a theoretical overview of entrepreneurs and intrapreneurs, and lists the most important content theories of motivation. Moreover, the paper elaborates on various motivational factors used in the research. Extrinsic motivational factors which were examined in the research are: monetary reward, challenge, and training, while intrinsic factors examined in the research are: power, affiliation, and recognition. Semi-structured interview as a form of qualitative research method was used in order to examine the influence of intrinsic and extrinsic factors on the motivation of entrepreneurs and intrapreneurs. Results show that entrepreneurs are more motivated by money and power compared to challenge and recognition as prime motivators of intrapreneurs. Training, affiliation and success were equally motivating for entrepreneurs and for intrapreneurs.
\end{abstract}

Key words: corporate entrepreneurship, entrepreneur, intrapreneur, qualitative research, motivation 